\title{
MEDIATING ROLE OF ENTREPRENEURIAL ORIENTATION, ORGANISATIONAL LEARNING AND SMES' PERFORMANCE
}

\author{
KOWO SOLOMON AKPOVIRORO ${ }^{1}$ \\ Department of Business and Entrepreneurship, \\ Kwara State University
}

\author{
AKINBOLA OLUFEMI AMOS \\ Department of Business Administration, \\ Federal University of Agriculture \\ OYEDELE OLA OLUSEGUN \\ Department of Entrepreneurship Studies, \\ University of Agriculture Abeokuta
}

\begin{abstract}
The cornerstone of entrepreneurship is Entrepreneurial Orientation (EO) and it is one of the significant predictors of SMEs performance. The concept of EO has been widely discussed through previous studies in entrepreneurship, so it can be considered as one of the main topics in this field, and the most commonly used measure of entrepreneurial behaviour or inclination in strategies and entrepreneurship studies. EO has emerged as an area of research, and EO impact studies have become a sub-field in Entrepreneurship Education research. The objectives of the study were to determine the effect of organisational learning (OL) on SMEs performance and also to examine the effect of innovative performance on EO. The study population refers to the managers of SMEs registered with the Small and Medium Enterprises Development Agency of Nigeria (SMEDAN) in Lagos State, Nigeria. Analysis of variance (ANOVA), correlation efficiency, and regression analysis was employed. The research found that EO affects organisational learning in an SME context. EO has a strong effect on learning and expands learning scope by encouraging companies to challenge the status quo and to make it more flexible and alter the way they work. There is a significant and positive relationship between entrepreneurial orientation and organisational learning within firms because it was revealed that entrepreneurial orientation has different impacts on the individual components of strategic learning. Moreover, the results of the study indicated that EO affects innovative performance. Entrepreneurialism significantly affects innovation and
\end{abstract}

Contact: Kowo Solomon Akpoviroro, kowosolomon@gmail.com, Department of Business and Entrepreneurship, Kwara State University, Malete, Nigeria. 
performance. Innovativeness, proactiveness and risk-taking have a strong impact on creating innovation, and entrepreneurial activity which enhances innovative behaviour. The study recommends that SMEs in Nigeria should be more proactive in developing strategies, improving operations, and paying attention to entrepreneurial orientation and organisational learning. Entrepreneurial orientation behaviours should be strengthened within SMEs, and should take advantage of the outputs in order to develop organisational learning processes, creative performance, corporate performance, improved decision-making processes, and adaptation to a rapidly changing work environment. Additionally, managers of these enterprises should encourage risk-taking in new initiatives and project planning processes.

Keywords: Nigeria, Entrepreneurial Orientation (EO), Organisational Learning (OL), Entrepreneurship, Innovativeness, SMEs' Performance

JEL Classification: L26, M53, M1

\section{INTRODUCTION}

The significant impact of small-medium enterprises (SMEs) on a developing economy is increasingly recognised (Alayo et al., 2019). They have often been acknowledged as productive and efficient job creators, large-scale seed companies and national economic engines (Short et al., 2018; An \& Kang, 2016). In the world's economy, professionals, politicians and scholars have been increasingly concerned with the study of entrepreneurship and SMEs (Lonial \& Cater, 2015). Entrepreneurship has been recognised widely in developing countries as an influential instrument for poverty reduction and an enhancer of economic growth (Alexe \& Alexe, 2018). All countries in general and developing countries in particular, seek to enhance and develop the entrepreneurial business to support the economic improvement and stability (Alshezawi \& Khan, 2018). Entrepreneurship is currently the primary cause of development, and is considered the driving force behind financial and social growth in most advanced and developing countries. Studies show that entrepreneurs play key roles particularly in the creation of small and medium enterprises, leading to higher employment (Ugoji, Mordi \& Ajonbadi, 2014). Because of its great ability to create new jobs, entrepreneurship is an essential factor for economic growth (Okta et al., 2015; Al-Harthi, 2017). Moreover, entrepreneurs play a very prominent role in employing the rural population, provide self-employment to those who start their own business and enhance the economic environment of the different sectors (Gao, 2017).

Furthermore, entrepreneurial orientation represents the management's orientation towards seeking new vistas for the firm's progression in a competitive environment. As a result, firms with focus towards entrepreneurship show a higher tendency towards realising growth through the process of exploratory 
strategic actions rather than the exploitative ones (Siren et al., 2017). EO helps to achieve sustainable performance. Entrepreneurial orientation is a key source of intangible value for organisations to sustain the competitive advantage for organisations through highlighting the new opportunities available in the business environment (Adams, Martin \& Boom, 2018; Youssef et al., 2018; Kowo \& Adenuga, 2019), exploiting them optimally and making them successful (Basson \& Erdiaw, 2019), especially in a highly competitive business environment. Entrepreneurial orientation supports the flexibility of organisations as a strategy to address environmental uncertainty. The ability of an organisation to develop new products, provide distinct product alternatives, and adjust production level as needed can be stimulated through autonomy, risktaking, innovativeness, competitive aggressiveness and proactiveness (Gal, 2018). Likewise, entrepreneurial orientation affects several organisational outcomes within any organisation, such as firm performance (Albtoush, 2015; Thomas, 2013), organisational learning (Sheng \& Cheien, 2016; Abasi, Akbari \& Tajeddini, 2015), innovative performance (Yildiz, 2014; Soedarmano et al., 2019) and firm performance (Bengig et al., 2018).

The entrepreneurial environment in Nigeria is still in progress, but actions can be taken to support the growth of national entrepreneurship. Nigeria can promote and stimulate entrepreneurial growth by providing favourable environmental factors. Political stability in the Sultanate is based on global ratings and is the most appealing feature. It also has a policy of free economy that is essential for new companies (Adisa, Adeoye \& Okunbanjo, 2016). The government in Nigeria has taken initiatives to promote its SMEs, but gaps still exists (Alayo et al., 2019). In order for SME owners to be able to readily start their own businesses and provide jobs in a market, the government has provided short term loans. Researchers have clarified that SMEs can succeed if they receive long-term loans at low financial cost as this makes it easy for owners to repay their loans (Seifari \& Amoozadeh, 2014). SME short-term loans always hamper the success of a company, even an excellent one (Al Bulushi \& Bagum, 2017). The SME sector in Nigeria begins the growth curve, and this sector needs a high level of governmental assistance. Nigeria SME contribution to GDP is small but helps the country to reduce the volume of unemployment (Okta et al., 2015). According to Ugoji, Mordi and Ajonbadi (2014) there were about 132,735 SMEs in 2013, most of them in the Lagos area. Kowo, Sabitu and Adegbite (2018) reported that $70 \%$ of SMEs are micro-enterprises, $25 \%$ of which were small and $5 \%$ were medium-sized in 2013. Adeiza, Malek \& Ismail (2017) highlighted how the Nigeria government took extraordinary actions to enhance its SMEs and the economy of its entire country in 2015. Nearly $90 \%$ of private industry is based on SMEs and it offers many job opportunities for young people, resulting in a significant fall in national unemployment over the last two years (Al Bulushi \& Bagum, 2017). The research seeks to answer the following questions (1) Does organisational learning (OL) affect SMEs performance? (2) What is the effect of innovative performance on $\mathrm{EO}$ ? 


\section{LITERATURE REVIEW}

\section{The Concept of Entrepreneurship}

In 1732, the Irish economist Richard Cantillon used the concept of entrepreneurship in reference to individuals who are ready to carry out types of arbitration concerning the financial risk of a new venture (Valerio, Parton \& Rebb, 2014; Gu \& Quian, 2019). Entrepreneurship requires more studies to indicate and define its main elements, for despite the efforts of previous studies, there is no satisfactory definition (Short et al., 2018). Zampetakis et al., (2015) mentioned that the concept of entrepreneurship is multi-dimensional. In this vein, there are several definitions of the concept. In addition, studies related to the definition of entrepreneurship and its role in the economy can be categorised in different ways such as chronology, in the school of thought and jobs attributed to entrepreneurs (Yildiz, 2014). Kao, Tsaur and Wu (2016) argued that many factors influence developing a comprehensive concept for entrepreneurship. Some of these factors are related to the culture, the economy or the society. Because social and economic factors are not consistent, according to the surrounding environment, it is fair to say that there is not yet a comprehensive definition of the concept of entrepreneurship, which includes all types and characteristics of entrepreneurship. According to Genc (2017) the reason behind not developing a global definition is that entrepreneurship has been documented in various disciplines, resulting in many opinions about its meaning. Eddleston \& Kellermans (2007) clarified that at present entrepreneurship is one of the most interesting and contentious study fields. The distinction in entrepreneurial definitions is due to each industry class having its distinct schools and views. Some definitions can be simple or general, such as 'the beginning of a new project' whilst others refuse to confine it in such a way, since firms could be characterised as entrepreneurial firms even though they are not involved in any new projects (Cherchem, 2017; Adenuga, 2009).

Entrepreneurship can be accurately defined as a type of mindset that views the world as a place to experiment and explore new possibilities in order to realise the true potential of one's quest for self-attainment through innovation and creativity (Alexe \& Alexe, 2018). Additionally, Alayo et al (2009) defined an entrepreneur as someone who looks for chances in the business environment and has the indispensable resources to create and develop a project to meet stakeholders' needs or to face and solve difficulties within the community. In the case of Zampetakis et al., (2009), entrepreneurship is described as a human activity taken at a person's own risk for the purpose of profit. Similarly, Solikahan and Mohammad (2019) mentioned that entrepreneurship is the process where the entrepreneur shapes a venture by looking at a market chance, accepts risks by supporting an efficient innovative idea or procedure and gains profits from the project. The word 'entrepreneurship' is "entrepreneurial ability and desire to create, organise and administer a company enterprise along with all its hazards to gain profit (Sismanoglu 
\& Akcah, 2018). Thomas (2013) defined it as the capacity of an individual to transform ideas and suggestions into action. It includes the capability to create, innovate and take risks in order to achieve objectives, to plan and manage projects. It promotes all people in their lives, both in their homes and in society. It also helps workers to be more conscious of the context of their job and to make better use of opportunities, and offers a basis for entrepreneurs to start up a social or business activity. As for the definitions of entrepreneurship, the concept of an entrepreneur was discussed intensively in various studies from different perspectives that focused on the entrepreneur's characteristics, or the entrepreneurial process and opportunity (Shahzad, Xiu \& Shahbaz, 2017; Kohtamaki et al 2019; Almanum and Fazal, 2018; Akinbola, Ogunnaike \& Aimaihian, 2015).

\section{ENTREPRENEURIAL ORIENTATION}

In recent years, academic and business interests have continued to focus on entrepreneurship orientation (Bendig et al., 2018), internationalisation and competitive strategies (Gu \& Qian, 2019). Kellermanns et al., (2016) and Yildiz (2014) added that entrepreneurial orientation (EO) as a differentiating firm factor in the entrepreneurship literature has been consolidated. $\mathrm{EO}$ has become a key concept in entrepreneurship, which has received considerable theoretical and empirical attention (Short et al., 2018; Kohtamaki et al., 2019). Entrepreneurs have an entrepreneurial orientation (EO) that indicates the procedures, structures, and behaviour of the firm to take advantage of opportunities. Sustainable entrepreneurs are described by previous literature as agents of change with the ability to disrupt an unsustainable system of industries and engage in complex entrepreneurial and sustainability trade-off decisions (Gao, 2017). Thomas (2013) argued that entrepreneurial orientation is reflected in the execution processes of organisations and organisational culture. It is a vital element for achieving higher performance through differentiation, developing better alternatives before competitors, supporting adaptation to environmental changes and market trends, weakening competitors' competitiveness and responding to future actions rapidly (Siren et al., 2017). The cornerstone of entrepreneurship is EO and it is one of the significant predictors of firm performance (Yildiz, 2014).

Kohtamaki et al. (2019) reported that the concept of EO has been widely discussed through previous studies in entrepreneurship, so it can be considered as one of the main topics in this field, and the most commonly used measure of entrepreneurial behaviour or inclination in strategies and entrepreneurship studies. The knowledge of $\mathrm{EO}$ has been further extended and has greatly benefited from two important constructs. This construct basically recognises EO as having a basic and unidimensional strategic orientation that is self-evident in the simultaneous existence of three elements, innovativeness and proactiveness behaviours, as well as risk-taking which is considered an attitudinal propensity. In particular, innovativeness and ingenuity ascribes to the notion of enhancement of creative procedures that could in fact lead to the creation of new products, services or 
technologies (Gu \& Qian, 2019; Short et al., 2018). Proactiveness indicates a desire to pursue self-motivated willingness to enhance current situation and create an environment conducive for growth as well as incubation for germinating of new opportunities, while risk-taking refers to the courage and ability to channelise investments and efforts in uncertain domains in order to capitalize on exponential return possibilities in terms of gains (Lonial \& Cater, 2015). The second idea anticipated by Siren et al (2017) is multidimensional, as it does not mandate simultaneous or parallel occurrence of different elements and offers two new cofactors, namely, competitive aggressiveness and autonomy, which together profess a strategy to challenge competitors in order to outsmart rivals in the industry, and to continuously focus on a single minded aim to excel and pursue options and directions that leads to the pursuit of opportunities and growth (Alayo et al., 2019).

In addition, $\mathrm{EO}$ is an organisational concept that demonstrates the managerial ability through which companies execute proactive and aggressive initiatives to achieve competitive advantage. Other researchers emphasised an expanded definition of the EO (Youssef et al., 2018; Adams, Martin \& Boom, 2018). Similarly, EO becomes an outstanding feature for high performing organisations (Ghazikalaye \& Roshani, 2016). Gloss, Pollack \& Ward (2017) also stated that entrepreneurial orientation represents the management's orientation toward seeking new opportunities for firm growth. Hence, entrepreneurial orientated firms are more ready to achieve growth via exploratory strategic actions (e.g., developing new product) rather than exploitative activities (e.g., advertising) (Gloss, Pollack \& Ward, 2017; Soedarmano et al. 2018; Sheng \& Chien, 2016; Adenuga, 2015; Gao, 2017; Thomas, 2013).

\section{SMEs Performance}

Understanding the factors that lead some enterprises to be more competitive than their competitors and thus making a bigger profit than their competitors is a matter of interest not only for academics, but also for managers (Abdullah, Musa \& Azis, 2017). Alexe and Alexe (2018) and An \& Kang (2016) argued that it is important for management to use external sources of information to adapt and respond to more complex and rapid changes in a dynamic business environment and use these sources to continue and survive in the work environment. Adiiza, Seifari and Amooza (2017) pointed out that the need to acquire and manage knowledge is emphasised to increase the overall performance and achieve competitive advantage. Various researchers have been attracted to exploring enterprise broadly, as its action contributes to macroeconomic results, as well as to SMEs performance. Performance change is the essential objective of entrepreneurial firms, as it exhibits the level of accomplishment of their business operations. Different firm performance estimations have been connected in earlier business research. In any case, the lion's share of these examinations did not give any support to the choice of measures utilised (Youssef et al., 2018). While exact estimation is urgent to seeing the SMEs performance, there has been 
no agreement among business enterprise researchers on the task of a suitable arrangement of estimations (Gal, 2018; Siren et al., 2017). Albtoush (2015) added a definition for measuring SMEs performance which combined financial and non-financial measures to evaluate it. Adams, Martin and Boom (2018) gave a characterisation plot that clarifies the area of business performance. They claimed that business performance is a subset of the general idea of hierarchical viability, and that thorough business performance covers monetary performance, as well as operational performance. The last incorporates indicators identified with mechanical productivity, such as product quality and advertising adequacy. Previous studies have shown that there is no consensus on how to measure a company's performance (Soedarmono et al., 2019; Alayo et al., 2019).

\section{The Concept of Organis ational Learning}

Although the concept of organisational learning has grown in academic researches within the last two decades (Short et al., 2018; Gu \& Qian, 2019), there is still a need for further research to explore the actual practice and actual activity that leads to learning (Gal, 2018). Basson and Erdiaw (2019) illustrated that organisational learning, the process through which organisations create, spread and exploit knowledge, and convert it into innovation is a major issue in organisational studies. Organisational learning does not occur in isolation, but is strongly influenced by institutional contexts (Akinbola, Sanni \& Akinbola, 2018; Alshezawi \& Khan, 2018; Valerio, Parton \& Robb, 2014). Langerud (2007) confirmed that organisational learning is considered a source of continuous success in a rapidly changing business environment. Tafvelin et al. (2017) revealed that there are no more studies that discussed organisational learning as an organisational phenomenon, and identified its antecedents and performance outcomes, innovation capacity (Ugoji, Mordi \& Ajonbadi, 2014) and customer value (Thomas, 2013).

Organisational learning is a major organisational capacity that occurs when organisations develop an in-depth learning culture and have educational, training and guidance systems to promote organisational learning (Sheng \& Chien, 2016). Researchers identified organisational learning in several different ways according to different perspectives (Zampetakis et al., 2015). Likewise, organisational learning is the method of building and complementing organisations, and organising knowledge and routine actions around their activities and cultures, in order to enhance organisational efficiency through optimal use of the distinctive skills of their employees (Solikahan \& Mohammad, 2019). Coco and Quttainah (2015) identified organisational learning as the processes of creating, spreading, sharing and transferring knowledge within the organisation and integrating it in practices. According to Kao, Tsaur and Wu (2016), organisational learning is also described as an expansion of the organisation's ability to implement effective arrangements by enhancing its performance and outcomes directly and systematically. Further, organisational learning is the knowledge and capabilities 
available at any time in any organisation, regardless of the persons involved (Kohtamaki et al., 2016). Organisational learning is a context-based process in which organisations seek to achieve the desired results (Siren et al., 2017).

Several studies have emphasized the importance of organisations' involvement in the changes needed to be able to cope with a changing business environment and achieve sustainable competitive advantage. Learning is crucial in this regard. It provides the organisation the capability to learn from the past, understand what has been learned and integrate it into the organisation's practices in a way that provides the organisation with the ability to adapt rapidly to changing circumstances (Yildiz, 2014). Sismanoglu and Akcali (2016) revealed that managerial literature indicates the vital role which organisational learning plays in supporting the sustainable competitive advantage of the organisation. Furthermore, learning plays an important role in enhancing the ability of organisations to reach speed and flexibility in the process of innovation (Okta et al., 2015; Valerio, Parton and Robb, 2014; Almamum and Fazal, 2018; Adenuga, 2009; Kohtamaki et al., 2019; Gal, 2018). Organisational learning and innovation have recently been revealed to be closely related to entrepreneurial orientation (Cherhem, 2017; Adisa, Adeoye \& Okunbanjo, 2016; Genc, 2017). Al-Harthi (2017) showed that many organisational and management practices studies discussed the effect of organisational learning on the performance of an organisation. Many previous studies have indicated that organisational learning can influence and enhance the organisation's performance, such as developing a new creative product and creating a learning culture within the organisation (Alayo et al., 2019; Adams, Martin \& Boom, 2018; Kalmuk \& Acar, 2015).

\section{Components of Organisational Learning}

Gloss, Pollack and Ward (2017) depicted five vital components of effective organisational learning, namely, "personal mastery, mental models, shared vision, team learning, and systems thinking", and the term of organisational learning has become well-known.

\section{Personal Mastery}

Motivates members to continually learn (Gao, 2017). As Gloss, Pollack and Ward (2017) mentioned, organisations cannot learn without employees desiring to learn. Learning develops the personal abilities of people to achieve their goals. Basson and Erdiaw (2019); Adeiza, Malek and Ismail (2017); Adenuga (2015); and Youssef et al. (2018) added that there is a need for employee commitment to learning in order to achieve competitive advantage in the labour market. Thomas (2013) reported that personal mastery includes creative personal development, enough effort, detecting opportunities and challenges in a changing business environment, employees' abilities to learn, and developing their skills and uniqueness. 


\section{Mental Model}

Shahzad, Xiu and Shahbaz (2017) stated that mental model is a way to develop your mind to produce the thoughts in different ways. It is an elucidation of thought process of an individual about how conceptual frame work can be applied in real practice with the help of our understanding. It represents the surrounding environment and its parts and an individual's perception about his or her performance and their magnitudes. Further, Zampetalkis et al., (2015) and Al-Harthi (2017) mentioned that mental models are "deeply ingrained assumptions, generations, or even pictures and images that influence personal and organisational views and behaviours and limit thinking". It is very important for an organisation to understand mental models, putting them into question and changing them according to surrounding reality (Almamum \& Fazal, 2018). Gloss, Pollack and Ward (2017) stated that mental models determine how a person thinks and acts. Although employees do not act according to their mental models, their behaviours are deepened on a mental image. Short et al. (2018) revealed that, within the learning organisation, mental models include the discipline of consideration, discussion, dialogue, and study. Employees try to reach acceptance about suitable and realistic mental models through this discipline. Sheng \& Chien (2016) explained the importance of mental models in detecting shortcomings in the present ways of looking at the labour market.

\section{Shared vision}

The appearance of shared vision came from employees having a strong personal vision sense, who see the team vision that can include the personal visions of all and who care about their work (Thomas, 2013). Eddleston \& Kellermans (2007) mentioned that a shared vision form believes that action and reaction with employees' awareness of organisation goals and agreement between employees' visions and developing these visions shape a shared vision. Abbasi et al. (2015) and Gal (2018) added that employees must understand and contribute to the vision of the organisation. Moreover, Kohtamaki et al. (2019) stated that shared vision is an organisational resource whereby employees share a desired future image. Additionally, Shahzad, Xiu and Shahbaz (2017) reported that shared vision builds a sense of commitment to the strategic objectives of organisations and common direction.

\section{Team learning}

Team learning is an important component of the learning organisation (Abbasi et al., 2015) due to the fact that teams represent the fundamental learning units in contemporary organisations (Alexe \& Alexe, 2018). According to Alayo et al., (2019) "unless teams can learn, the organisation cannot learn". Team learning includes the fact that thinking, communication, and stimulation through the team are more important than thinking individually. It is valuable (Ghazikalaye \& Roshani, 2016). 


\section{The CONCEPT OF INNOVATIVE PERFORMANCE}

Today's business environment is unpredictable and volatile, and companies have to modify and adapt constantly to survive. New ideas, strategies, processes, new markets, products and services contribute to innovation to cope up with volatility (Kowo \& Adenuga, 2019). Innovation is an essential tool for developing strategies; it can enable companies to distinguish their products, increase efficiency, permeate new markets and increase market share to demonstrate their competitiveness (Lonial \& Cater, 2015; Genc, 2017). Albtoush (2015) asserted that companies have always been required to enhance innovations to ensure they keep a competitive advantage. Within the competitive business environment, organisations have begun to develop innovative performance to achieve greater success and remain in competitive markets (Almamum \& Fazal, 2018).

Likewise, innovation is one of the main characteristics of entrepreneurial behaviour that has been strongly connected to small and medium enterprises (Okta et al., 2015; Soedarmono et al., 2019; Siren et al., 2017). Cocco and Quttainah (2015) mentioned that innovation is designing, creating, developing or implementing new products, services, systems, organisational structures, new models or business models to generate new value for customers and financial revenues for the company. According to Abasi et al. (2015), innovation is described as the applying of new ideas or behaviour in the organisation's products, services, systems, policies and programs to adjust to the environment and to enhance efficiency and competitiveness. Moreover, innovation refers to the reduplicating process involved in developing and marketing products and services as a response to new opportunities, and coincides with ambitious commercial success (Sismanoglu \& Mohammad al, 2019). Zampetakis et al., (2015) defined innovation as the instrument tool for entrepreneurs and firms that leads to the development of the strong and dynamic SME sector. Knowledge is an essential tool for innovative performance. Kao, Tsaur and Wu (2012) indicated that innovative performance must be clearly defined to increase our understanding of some technical issues relevant to the influences of organisational learning capacity. Innovative performance refers to the development of products, processes, and procedures that increase the relevance, utility and performance of products and services by using new ideas and creativity (Gu \& Qian, 2019; Adisa, Adeoye \& Okunbanjo, 2016).

\section{THEORETICAL REVIEW}

\section{Resource Based Theory (RBT)}

Edith Penrose (1959) developed the Resource Based Theory (RBT), which examines the role of resources in the growth or empowerment of company hierarchies. She describes "the physical items which a company purchases, rents 
or provides for its own use and the general population are enlisted according to conditions which make them an appropriate part of the company" (Penrose, 1959). Over 50 years, researchers have based their research on Penrose's bits of knowledge, and with the development of the RBT, analysts have concentrated on "vital assets" (Lonial \& Carter, 2015). Vital properties are those properties of (1) value that can be used for expanding customer confidence or decreasing costs; (2) are so rare that rivals do not approach the same or basically the same resources to dispute the appreciation; and (3) are difficult to replace and further imitate, so that the organisation can stay ahead of its rivals (Barney, 1991). The focus of the RBT is on improving company efficiency in a way that a company has vital assets (Barney et al., 2001), and the present meta-inquiry confirms the validation of that statement (Lonial \& Carter, 2015). At first, the RBT grew in the field of management. Lonial \& Carter (2015) have developed the concept of vital administration. They indicated that core management handles the significant anticipated and emerging operations of general supervisors, including the use of resources to enhance business efficiency by owners. "Therefore, essential administration directs managers and corporation manages persons or groups of individuals acting freely or as a function of a company structure, forming or reinventing new associations" (Sharma \& Chrisman, 1999; Kellermanns et al., 2016). The RBT examines the suitability of the assets of companies to achieve strong efficiency with their characteristics. RBT's most distinctive achievement is the plan of criteria that must be met to ensure the company's continued advancement of assets (Kellermanns et al., 2016). Jay B. Barney (1991), who declared that a company's assets preserved its upper hand, produced one of the most convincing texts of essential administration in history. He explained that a company is said to be upper-hand when it updates a value scheme which any current or potential competitor executes at the same moment, and when those various companies are unable to copy the benefits of that scheme. Early RBT work identified that the company is a complex asset-based structure (Kellermanns et al., 2016; Lonial \& Carter, 2015; Martin \& Javalgi, 2016).

In any case, RBT has become the world's main view for key management assessments (Peteraf, 1993), and having an RBT-business interface is a minimal requirement in providing a "research setting" for observational work (e.g. Lonial \& Carter, 2015), Because most asset-based studies fail to account for the thinking of the company, RBT fails to a considerable extent to include imagination and entrepreneurial demonstration (Barney et al., 2001). A company's asset perspective suggests that corporate performance is clearer against corporate assets in comparison to industry structure (Martin \& Javalgi, 2016). Assets in nature may be singular or meaningless. Capital and access to capital are incorporated in substantial investments. Little companies from a resource-based perspective have had hardly any investigation (Lonial \& Carter, 2015), yet small companies are likely to rely heavily on ownership / managers' assets. This applies in particular to women businessmen, as they tend to be in management or retail, and $85 \%$ of these organisations have no assets other than those belonging to 
their managers (Barney, 1995). The company's resource basis perspective (RBV) has proven to be one of the most commonly used hypotheses in management studies. The central premise of RBV is that the company produces upper hands, thanks to its outstanding asset structure (Lonial \& Carter, 2015). In keeping with the end objective of economic superiority, Barney (1991) identified four main characteristics that an asset must have: it must be important, unusual, incomplete and non-replaceable. Most RBV Scientists use this concept to describe and operate advanced developments. Ultimately, companies should be able to support preferences taken from prevailing assets.

The mainstream comes from the assets and capabilities of an organisation that integrate the management capabilities, organisational processes and data, and information (Barney, 1991). In a concentrated environment, companies transmit their physical, human and organisational assets to take a favourable market position (Martin \& Javalgi, 2016) If assets and capacity are profitable for customers and are unusual and difficult to copy, they offer a sustainable advantage, which increases company performance (Lonial \& Carter, 2015; Martin \& Javalgi, 2016). Hence, hierarchical introductions can give a manageable position and create unrivalled results on the part of an organisation. Analysts have noticed the importance and the relative links between $\mathrm{EO}, \mathrm{MO}$, and $\mathrm{LO}$ and the organisational outcomes (Martin \& Javalgi, 2016). In turn, organisations with these organisational capabilities are performing in the market at an unusual level. In the current market companies, the continuing cycle of maintenance and improvement of the businesses is up against exceptional operating conditions. In this environment, companies should effectively utilize important, noteworthy and difficult to duplicate substantial and immaterial resources. According to the resource-based view, Barney et al. (1995) propose that organisations use their physical, human and hierarchical resources to build their reach over lengthy distances, and so perform with unrivalled success (Martin \& Javalgi, 2016). Elusive hierarchical resources such as entrepreneurial orientation, organisational learning capability (OLC) and innovation performance (IP), for example, are difficult for competitors to copy, so these favourable, feasible circumstances are prompt (Martin \& Javalgi, 2016).

\section{RESEARCH GaP}

Nigerian SMEs have an important influence on the Nigeria economy. In order for small and medium enterprises to prosper and survive in a dynamic business environment, they must design and implement their philosophy in enterprise activities. The influence of $\mathrm{EO}$ on a company's performance is generally considered within the business field, but the findings vary from an immediate positive to no critical correlation between the entrepreneurial orientation and performance (Kohtamaki et al., 2014; Youssef et al., 2018). This study confirms that such variations are due to cultural characteristics related to the Africa environment, given that EO in SMEs requires a property (Thomas, 2013; Ugoji, Mordi \& Ajonbadi, 2014). More studies have been called for to determine in what way an EO can be beneficial. 
This paper attentively tests the effect of organisational leaning on entrepreneurial orientation. Organisational learning allows a company to mix its present assets and capabilities, transforming them into specific economic advantages (Alayo et al., 2019). Hierarchical learning becomes an essential part of the strategy based on resources and its enhancement as well as the approach being based on knowledge. Both hypothesis systems advice that the upper hand is the capacity and skills of the company and hierarchical learning requires both if it is to improve the efficiency of the organisation and strengthen its advantage. Additionally, Valerio, Parton and Robb (2014) found that a positive and direct relationship existed between entrepreneurial orientation and firm performances. This relationship requires extensive investigation in the Africa. Also, previous studies have indicated the impact of OL on business performance (e.g. Short et al., 2018; Okta et al., 2015; Gal, 2018). Siren et al. (2017) revealed that introduction to learning takes place at the corporate culture stage in particular and different variables can interfere with the relationship between learning introduction and business results.

Moreover, prior studies have revealed certain questionable results regarding the connection between hierarchy and business performance (Shahzad, Xiu and Shahbaz, 2017; Kellermanns et al., 2016; Genc, 2017). However, the significance of organisational leaning as an EO history has been emphasised by prominent researchers such as Adams, Martin and Boom (2018); Coco and Quttainah (2015) and Kellermanns et al. (2016), yet the relationship between OL and EO is rarely investigated (Gu \& Qian, 2019). Many researchers, such as Alayo et al (2019) and Adenuga (2015), have called for further consideration of such a relationship. Likewise, many previous studies have indicated the positive impact of organisational leaning on entrepreneurial orientation (e.g. Kohtamaki et al., 2019; Brettel. Chomik \& Flatten, 2015;Gal, 2018; Kellermanns et al., 2016). Kao, Tsaur and Wu (2016); Gao (2017); Seifari \& Amoozadeh (2014); An \& Kang (2016) and Eddleston \& Kellermans. (2007) have confirmed that EO correlates positively with firm performance. Furthermore, entrepreneurial orientation positively affects organisational learning (Genc, 2017; Sheng \& Chien, 2016) and innovative performance (Lonia \& Cater, 2015; Alexe \& Alexe, 2018; Youssef et al., 2018). Yet the relationship between Organisational leaning and EO is not ascertained (Zampetakis et al., 2015; Basson \& Erdiaw, 2019; Short et al., 2018). Many researchers, such as Yildiz (2014) and Okta et al. (2015) have called for further consideration of such a relationship.

\section{METHOD}

This section discusses the methodology of the study and research design. It introduces research philosophies, research approach, data sources, and research design. Additionally, it details the use of the survey method, sampling design, questionnaire development, questionnaire design, and measurement. In addition, the techniques of the data collection employed and the application of the study strategy are covered. The expo factor method was used. Furthermore, the current quantitative phase of the data collection, through which a description of the methods 
used in implementing the quantitative phase in this study were also provided. The argumentation begins with the justification behind selecting a sample survey method. The study adopts a self-administered survey for data collection, as detailed. Moreover, the research focused on the survey design, the pilot study applied to test different issues in the study strategy and the study's latent variables (Gill \& Johnson, 2010). In addition, the questionnaire was the research instrument for this study's description, and their related indicators are provided. The research's data preparation technique employed to verify the data accuracy was discussed, followed by the data preparation, which includes dealing with missing values and outlier issues.

The issue of the methodology of choosing the methods of data collection to be used for the study depends on the fact that what are the aims and objectives of the research under consideration (Easterby-Smith et al., 2011; Cresswell, 2009). Primary data was used for this study. Furthermore, the collected data was employed to propose a possible understanding of the study's variables' relationships. Therefore, the current study sample units have been chosen as SME managers. A survey is used to collect data for theoretical model validity purposes. The study population refers to the managers of SMEs registered with the Small and Medium Enterprises Development Agency of Nigeria (SMEDAN) in Lagos State. The sample frame was obtained from the (SMEDAN), the surveyed SMEs were randomly selected from the sample frame. The sample size was determined using the Yamane formula (Gefen et al., 2000; Cresswell, 2009).

Therefore, the sample size was determined by $n=\frac{N}{1+N(e)^{2}}$, where $n=$ the sample size; $N=$ population; $e=$ the limit of tolerance.

$$
\text { Therefore, } n=\frac{152}{1+152(0.05)^{2}}=\frac{152}{1+152(0.0025)}=\frac{152}{1+0.38}=\frac{152}{1.38}=
$$

$=110.14=110$ respondents (approximately).

A sample of one hundred and ten (110) employees out of the one hundred and fifty-two (152) employee population were selected; the simple random sampling technique was adopted. Towards this end, the test re-test reliability approach was adopted for the convenience of the researcher (Gill \& Johnson, 2010; Gefen et al., 2000). Cronbach Alpha coefficient and SPSS were adopted.

\section{DATA ANALYSIS}

Table 1

Distribution of respondents and response rate

\begin{tabular}{|l|c|c|}
\hline \multicolumn{1}{|c|}{ Respondents Customers } & $\begin{array}{c}\text { Questionnaire administered } \\
\text { (sampled) }\end{array}$ & $\begin{array}{c}\text { Percentage of total response } \\
\text { (\%) }\end{array}$ \\
\hline Top Level Managers & 53 & 53.0 \\
\hline Middle Level Managers & 20 & 20.0 \\
\hline Lower Level Managers & 27 & 27.0 \\
\hline Total & $\mathbf{1 0 0}$ & $\mathbf{1 0 0 . 0}$ \\
\hline
\end{tabular}




\begin{tabular}{|l|c|c|}
\hline \multicolumn{1}{|c|}{ Gender/Category } & $\begin{array}{c}\text { Questionnaire administered } \\
\text { (sampled) }\end{array}$ & $\begin{array}{c}\text { Percentage of total response } \\
\text { (\%) }\end{array}$ \\
\hline Male & 46 & 46.0 \\
\hline Female & 54 & 54.0 \\
\hline No of Returned & 100 & 83.3 \\
\hline No of Not Returned & 20 & 16.7 \\
\hline Total no of Questionnaires & $\mathbf{1 2 0}$ & $\mathbf{1 0 0}$ \\
\hline
\end{tabular}

Source: Field Survey 2020

Table 2

Descriptive Statistics of Entrepreneurial Orientation, Organisational Learning and SMEs' Performance

\begin{tabular}{|c|c|c|}
\hline Responses & \multirow{2}{*}{$\begin{array}{c}\text { Total } \\
(\mathbf{N})\end{array}$} & \multirow{2}{*}{ Mean } \\
\hline Organisational Learning and SMEs Performance. & & \\
\hline $\begin{array}{l}\text { Organisational learning is the knowledge and capabilities available at } \\
\text { any time in any organisation, regardless of the persons involved and also } \\
\text { Organisational learning is a context-based process in which organisations } \\
\text { seek to achieve the desired results }\end{array}$ & 100 & 4.81 \\
\hline $\begin{array}{l}\text { People are encouraged to interact with the environment: competitors, } \\
\text { customers, technological institutes, universities, suppliers, etc. }\end{array}$ & 100 & 3.98 \\
\hline $\begin{array}{l}\text { People here receive support and encouragement when presenting new } \\
\text { ideas. }\end{array}$ & 100 & 3.69 \\
\hline $\begin{array}{l}\text { Organisational learning is a major organisational capacity that occurs } \\
\text { when organisations develop an in-depth learning culture and has } \\
\text { educational, training and guidance systems to promote organisational } \\
\text { learning. }\end{array}$ & 100 & 3.79 \\
\hline $\begin{array}{l}\text { Organisational learning does not occur in isolation but is strongly } \\
\text { influenced by institutional contexts }\end{array}$ & 100 & 3.77 \\
\hline Innovative Performance and Entrepreneurial Orientation & Total & Mean \\
\hline $\begin{array}{l}\text { New ideas, strategies, processes, new markets, products and services } \\
\text { contribute to innovation to cope up with volatility }\end{array}$ & 100 & 3.89 \\
\hline $\begin{array}{l}\text { The glue that holds the company I work in together is an emphasis } \\
\text { on tasks and goal accomplishment. A production and achievement } \\
\text { orientation is commonly shared which has effect on EO. }\end{array}$ & 100 & 3.89 \\
\hline $\begin{array}{l}\text { Innovation is designing, creating, developing or implementing new } \\
\text { products, services, systems, organisational structures, new models or } \\
\text { business models to generate new value for customers and financial } \\
\text { revenues for the company. }\end{array}$ & 100 & 3.88 \\
\hline There is a positive relationship between innovative performance and EO & 100 & 3.87 \\
\hline $\begin{array}{l}\text { The glue that holds the company I work in together is commitment to } \\
\text { innovation and development. There is an emphasis on being first with } \\
\text { products and services. }\end{array}$ & 100 & 3.72 \\
\hline $\begin{array}{l}\text { Innovative performance is the construction of a composite based on } \\
\text { different performance indicators, such as new patents, new products, new } \\
\text { projects, new practices, and new organisational procedures }\end{array}$ & 100 & 3.79 \\
\hline
\end{tabular}

Source: Field Survey 2020 


\section{HYPOTHESIS ONE}

Ho: There is no significant relationship between Organisational learning (OL) and SMEs Performance.

Hi: There is significant relationship between Organisational learning (OL) and SMEs Performance.

Table 3

Model Summary

\begin{tabular}{|c|c|c|c|c|c|}
\hline Model & R & R Square & $\begin{array}{c}\text { Adjusted R } \\
\text { Square }\end{array}$ & $\begin{array}{c}\text { Std. Error of } \\
\text { the Estimate }\end{array}$ & $\begin{array}{c}\text { Durbin- } \\
\text { Watson }\end{array}$ \\
\hline 1 & $.349 \mathrm{a}$ & .122 & .116 & 1.703 & 1.997 \\
\hline
\end{tabular}

a. Predictors: (Constant), Organisational learning (OL)

b. Dependent Variable: SMEs Performance.

Source: Field Survey 2020

Table 4

ANOVAa

\begin{tabular}{|ll|c|c|c|c|c|}
\hline Model & $\begin{array}{c}\text { Sum of } \\
\text { Squares }\end{array}$ & Df & $\begin{array}{c}\text { Mean } \\
\text { Square }\end{array}$ & F & Sig. \\
\hline 1 & Regression & 63.476 & 1 & 63.476 & 21.897 & $.000 \mathrm{~b}$ \\
& Residual & 458.024 & 158 & 2.899 & & \\
& Total & 521.500 & 159 & & & \\
\hline
\end{tabular}

a. Dependent Variable: SMEs Performance.

b. Predictors: (Constant), Organisational learning (OL)

Source: Field Survey 2020

\section{INTERPRETATION OF RESULTS}

The result from the model summary table revealed that the extent to which the variance in SMEs Performance can be explained by Organisational learning $(\mathrm{OL})$ is $12.2 \%$ i.e. $\left(\mathrm{R}\right.$ square $=0.122$ ). The ANOVA table shows the $\mathrm{F}_{\mathrm{cal}} 21.897$ at a significance level. The table shows that both variables are significant at a significance level of 0.01 .

\section{Coefficients $^{\mathrm{a}}$}

Table 5

\begin{tabular}{|c|c|c|c|c|c|c|}
\hline \multirow{2}{*}{\multicolumn{2}{|c|}{ Model }} & \multicolumn{2}{|c|}{$\begin{array}{l}\text { Unstandardized } \\
\text { Coefficients }\end{array}$} & $\begin{array}{c}\text { Standardized } \\
\text { Coefficients }\end{array}$ & \multirow[t]{2}{*}{$\mathbf{T}$} & \multirow[t]{2}{*}{ Sig. } \\
\hline & & B & Std. Error & Beta & & \\
\hline \multirow[t]{2}{*}{1} & (Constant) & 10.617 & 1.504 & & 7.061 & .000 \\
\hline & $\begin{array}{l}\text { Organisational } \\
\text { learning (OL) }\end{array}$ & .396 & .085 & .349 & 4.679 & .000 \\
\hline
\end{tabular}

a. Dependent Variable: SMEs Performance.

Source: Field Survey 2020 
The coefficient table above shows that the simple model that expresses the relationship between SMEs Performance and Organisational learning (OL). The model is shown mathematically as follows: $y=a+b x$, where $y$ is SMEs Performance and $x$ is Organisational learning (OL), a is a constant factor and $\mathrm{b}$ is the value of coefficient. From this table therefore, SMEs Performance $=$ $10.617+0.396$ Organisational learning (OL). It shows that both tested variables are at a significance level of 0.01 , which means that there exists a significance relationship between Organisational learning (OL) and SMEs Performance.. Therefore, for every $100 \%$ increase in SMEs Performance, Organisational learning (OL) offer contributed 39.6\%. The significance level below 0.01 implies that a statistical confidence of above $99 \%$. This implies that there is a positive significant relationship between Organisational learning (OL) and SMEs Performance. Thus, the decision would be to reject the null hypothesis (Ho), and accept the alternative hypothesis (H1).

\section{HYPOTHESIS TWO}

Ho: There is no significant relationship between Innovative Performance and Entrepreneurial Orientation.

Hi: There is significant relationship between Innovative Performance and Entrepreneurial Orientation.

Table 6

\section{Correlations}

\begin{tabular}{|l|l|c|c|}
\hline \multicolumn{2}{|l|}{} & Free sample & Customer choice \\
\hline \multirow{3}{*}{$\begin{array}{l}\text { Innovative } \\
\text { Performance }\end{array}$} & Pearson Correlation & 1 & $.355^{* *}$ \\
\cline { 2 - 4 } & Sig. (2-tailed) & & .000 \\
\cline { 2 - 4 } & $\mathrm{N}$ & 100 & 100 \\
\hline \multirow{3}{*}{$\begin{array}{l}\text { Entrepreneurial } \\
\text { Orientation (EO) }\end{array}$} & Pearson Correlation & $.355^{* *}$ & 1 \\
\cline { 2 - 4 } & Sig. (2-tailed) & .000 & 100 \\
\cline { 2 - 4 } & $\mathrm{N}$ & 100 & \\
\hline
\end{tabular}

${ }^{* *}$ Correlation is significant at the 0.01 level (2-tailed).

Source: Field Survey 2020

Result: Pearson Correlation Value of the hypothesis is 0.355 having the r value of 0.001 (in which $\mathrm{P}$ - value is lesser than 0.01 ) it shows that the correlation result is considered to be significant. This shows a correlation between the dependent and independent variables with the value of 0.355 at a significance level. Hence, it is concluded that there is a significant relationship between Innovative Performance and Entrepreneurial Orientation (EO). Therefore, the decision would be to reject the null hypothesis ( $\mathrm{Ho})$, and accept the alternative hypothesis (H1). 


\section{The Mediating Role of Organisational Learning and SMEs Performance in the Context of the Relationship between $\mathrm{EO}$ and firm performance}

In order to answer the first question, the impact of $\mathrm{EO}$ on firm performance through the mediating role of organisational learning was investigated. The results of the study showed that EO affects organisational learning in an SME context. This result is in line with several studies. For example, Gal (2018) and Youssef et al. (2018) stated that entrepreneurial orientation has a strong effect on learning and expands learning scope by encouraging companies to challenge the status quo and to make it more flexible and alter the way they work. Moreover, there is a significant and positive relationship between entrepreneurial orientation and organisational learning within firms (Thomas, 2013; Lonial \& Cater, 2015; Soedarmono et al., 2019). Zampetakis et al. (2015) stated that entrepreneurial orientation positively enhances managing the organisational learning process and capacity. Also, Siren et al. (2017) mentioned that entrepreneurial orientation still requires organisational learning systems and activities to enable higher learning and innovation. In the same way, Kellerman et al. (2016) and Okta et al. (2015) stated that EO is one of the key factors that support learning, innovation and firm performance. Alayo et al (2019) confirmed the positive effect of entrepreneurial orientation on organisational learning capability and firm performance. Sirén et al. (2017) reported that entrepreneurship orientation has different impacts on the individual components of strategic learning.

\section{The Mediating Role of Innovation Performance in the Relationship between EO and Firm Performance}

In order to answer the second question, the impact of $\mathrm{EO}$ on firm performance through the mediating role of innovation performance was investigated. The results of the study indicated that EO affects innovation performance. This result is consistent with many previous studies. Previous studies by Adams, Martin \& Boom (2018); An and Kang (2016); AlBulushi and Bagum (2017); Short et al. (2018); Kohtamaki et al. (2019); and Youssef (2014) have confirmed the significant and positive relationship between entrepreneurial orientation and innovative performance. Further, Adisa, Adeoye and Okunbanjo (2016); Sheng and Chen (2016); Valerio, Parton and Robb (2014); Genc (2017); Gal (2018); Ugoji, Mordi and Ajonbadi (2014); Cherchem (2017); and Gloss, Pollack and Ward (2017) studies have concluded that entrepreneurialism significantly affects innovation and performance. According to Eddleston and Kellermans study, innovativeness, proactiveness and risk-taking have a strong impact on creating innovation, and entrepreneurial activity greatly enhances innovative behaviour.

\section{MANAGERIAL IMPLICATIONS}

The results of the current study delineate important implications for both organisations and employees. The study also concluded that organisational 
learning and innovation performance affect firm performance. Finally, the study confirmed that both organisational learning and innovation performance play partial mediating roles in the relationship between $\mathrm{EO}$ and firm performance. In the light of findings of the current study, small and medium enterprises in Nigeria should be more proactive in developing strategies, improving operations, and paying attention to entrepreneurial orientation and organisational learning. Entrepreneurial orientation behaviours should be strengthened within SMEs, and should take advantage of the outputs in order to develop organisational learning processes, creative performance, corporate performance, improved decisionmaking processes, and adaptation to a rapidly changing work environment. For this reason, the small and medium enterprises' managers and workers should enhance their practices of entrepreneurial orientation by providing new production lines, advanced technologies and new markets that support and encourage employees' involvement in developing creative ideas and design, and compete aggressively in the market by taking calculated risks.

Therefore, in order to generate more creative ideas from employees belonging to these enterprises, managers should empower employees by giving them the freedom to determine their own ways of doing work by discussing problems of work freely and openly, and also favourably acknowledging their opinions and suggestions in solving work-related problems. Additionally, managers of these enterprises should encourage risk-taking in new initiatives and project planning processes. Besides, an innate ability to take measurable risks in a typical small and medium. Hence, managers should not fear failure, as calculated risk-raking contributes to an organisation's growth. Aversion towards risk taking can lead to a slow and gradual downslide in a firm's performance, culminating in a total debacle. In addition, SME managers should provide an effective work environment focused on leveraging information technology, through which the organisation is able to achieve competitive advantages in the long run, because the focus on this technology provides information that enables the organisation to develop appropriate decisions and strategies to support the overall organisational performance. Furthermore, managers should be interested in continually searching for learning opportunities in order to gain experience and knowledge that will enable them to improve performance and achieve competitive advantage.

\section{THEORETICAL IMPLICATIONS}

The current study has many theoretical implications that can add to the body of knowledge in several ways. Firstly, in a small and medium enterprises context, EO has becomes an important factor that enhances performance. Identifying the mediating factors affecting the relationship between $\mathrm{EO}$ and firm performance provides a clear picture of a strategy to help improve a firm's performance through EO. Secondly, this study explores the mediating role organisational learning and innovation performance play in the relationship 
between $\mathrm{EO}$ and firm performance which has not been investigated in the small and medium enterprises sector before. Thirdly, previous studies have discussed the direct effect of $\mathrm{EO}$ on firm performance in countries other than the developed ones. This study explores the effectiveness of $\mathrm{EO}$ on a firm's performance through the mediating role played by organisational learning and innovation performance in different developing cultural contexts (such as Nigeria).

\section{CONCLUSION}

This research shows that Entrepreneurial orientation is an important tool in creating and developing innovative performance. EO capabilities are essential for company innovation because EO is linked with a methodology of experimenting with new activities, a desire to take advantage of new products, new markets, and new options and a company's propensity for risky enterprises. It was concluded that entrepreneurial orientation correlates positively with radical and incremental innovation. This result is further confirmed that entrepreneurial orientation plays an important role in enhancing marketing innovative performance in SMEs. Moreover, the findings of the study depicted that innovative performance positively affects firm performance in the context of SMEs. It was also asserted that effective management of organisational innovation enhances creativity and ultimately benefits the entire management. A firm's performance is significantly and positively affected by innovation because it was demonstrated that innovation adoption is a vital factor for organisational change in order to improve performance, particularly in the light of a lack of resources, a changing business environment, high competitiveness as well as changes in customer needs in terms of better quality. More so the study revealed that innovation capability has a strong effect on firm performance. Organisations can improve their financial performance through an organisational innovation strategy. The result of the study showed that innovation performance plays a partial mediating role in the relationship between EO and firm performance. This paper concludes that organisations encourage employees to demonstrate innovative behaviour in the workplace. The work environment transforms the basis of competitive advantage from quality to innovation. Innovation helps organisations to adjust rapidly to changes and helps create new products and markets, thereby protecting them from an unstable work environment. It was also concluded that a high level of performance is affected positively by a high level of innovation. Moreover, the study indicated that proactiveness, innovativeness and resource leveraging dimensions of entrepreneurial marketing are correlated positively with innovative performance.

\section{LIMITATIONS AND AVENUES FOR FUTURE RESEARCH}

The collected data in this study is cross-sectional in nature, and therefore it is recommended that future research make use of longitudinal data in order to better assess the relationship between $\mathrm{EO}$ and firm performance and how 
different forms of culture affect the dimensions of EO over time. A further possible area of research is to assess the influence of the external business environment (such as dynamism and hostility) on these various aspects of organisational learning and how firms can adapt in response to these environmental changes. Another limitation of the present study is the mixture of firms of different sizes. Contrary to small companies, larger organisations are very likely to be structured into divisions that require more fine-grained interpretation. In addition, although the study is limited to and constrained by employees' demographics, the research could argue that such factors may play a moderate role in the relationship between entrepreneurship orientation and firm performance. These study therefore further calls for a thorough as well as an intuitive investigation into such effects.

\section{REFERENCES}

1. Adenuga, O. A. (2015). Developing Entrepreneurial Skills among the Youth: An antidote for National Insecurity, The Lagos Counsellor 8 (1), 117-126.

2. Adenuga, O. A. (2009) Bullying at workplace: The Coping Strategies: African Journal of Research in Personnel and Counselling Psychology 1(1), 30-54.

3. Akinbola, O. A., Sanni, A. \& Akinbola, S. (2018). Appraisal of Entrepreneurship Capacity Programs and Internationalization of Small and Medium Enterprises in Nigeria: Acta Universitatis Danubius 14 (6), 72-89.

4. Akinbola, O. A., Ogunnaike, O. O., Amaihian, A. (2015) The Influence of Contextual Factors on Entrepreneurial Intention of University Students: The Nigerian Experience. Journal of South African Business Research, 4 (1), 197-203.

5. Abbasi, E., Akbari, M. \& Tajeddini, K. (2015). Organisational learning capabilities: Evidence from the Iranian agricultural higher education system. Iranian Journal of Management Studies, 8(1), 117-138.

6. Abdullah, S., Musa, C. I., \& Azis, M. (2017). The effect of organisational culture on entrepreneurship characteristics and competitive advantage of small and medium catering enterprises in Makassar: International Review of Management and Marketing, 7(2), 409-414.

7. Adams, R., Martin, S., \& Boom, K. (2018). University culture and sustainability: Designing and implementing an enabling framework. Journal of cleaner production, (171), 434-445.

8. Adeiza, A., Malek, M. A., \& Ismail, N. A. (2017). An Empirical Analysis of the Influence of Entrepreneurial Orientation on Franchisees: Outlet Performance and Intention to Stay. Korean Journal of Management, 8(1), 5-18.

9. Adisa, M. K., Adeoye, A. O., \& Okunbanjo, O. I. (2016). The impact of entrepreneurship orientation on entrepreneurs' compensation in Nigeria: International Journal of Economics, Business and Management Studies, 3(3), $102-116$.

10. Al Btoush, J. (2015). The relationship between corporate entrepreneurship and sustainable growth in engineering consultancy companies (Master Dissertation, College of Business Administration, Amman Arab University). 
11. Al Bulushi, B. H. S., \& Bagum, S. (2017). Growth strategies of sme in OmanIssues and challenges: International Journal of Small Business and Entrepreneurship Research, 5(2), 21-61.

12. Al Mamun, A., \& Fazal, S. A. (2018). Effect of entrepreneurial orientation on competency and micro-enterprise performance. Asia Pacific Journal of Innovation and Entrepreneurship, 12(3), 379-398.

13. Al Shezawi, H.A., \& Khan, F. R. (2018). In-Country Value (ICV)-Entrepreneurial Opportunities in the Companies of Oman: International Journal of Management, Innovation \& Entrepreneurial Research, 4(1), 25-41.

14. Alayo, M., Maseda, A., Iturralde, T., \& Arzubiaga, U. (2019). Internationalization and entrepreneurial orientation of family SMEs: The influence of the family character. International Business Review, 28(1), 48-59.

15. Alexe, C. G., \& Alexe, C. M. (2018). Similarities and differentiations at the level of the industries in acquiring an organisational culture in innovation: Procedia Manufacturing, 22 (1), 317-324.

16. Al-Harthi, A. A. (2017). Understanding entrepreneurship through the experiences of Omani entrepreneurs: implications for entrepreneurship education. Journal of Developmental Entrepreneurship, 22(01), 1750001.

17. An, Y., \& Kang, J. (2016). Relationship between organisational culture and workplace bullying among Korean nurses. Asian nursing research, 10(3), 234-239.

18. Basson, M., \& Erdiaw-Kwasie, M. (2019). Entrepreneurship under siege in regional communities: Evidence from Moranbah in Queensland, Australia. Journal of rural studies, 66, 77-86.

19. Barney, J. (1991). Firm resources and sustained competitive advantage: Journal of Management, 17(1), 99-120.

20. Barney, J. B. (1995). Looking inside for competitive advantage: The Academy of Management Executive, 9(4), 49-61.

21. Brettel, M., Chomik, C., \& Flatten, T. C. (2015). How organisational culture influences innovativeness, proactiveness, and risk-taking: Fostering entrepreneurial orientation in SMEs. Journal of Small Business Management, 53(4), 868-885.

22. Bendig, D., Enke, S., Thieme, N., \& Brettel, M. (2018). Performance implications of crossfunctional coopetition in new product development: the mediating role of organisational learning. Industrial Marketing Management, 73, 137-153.

23. Cocco, J., \& Quttainah, M. (2015). Creativity versus innovativeness: Exploring the differences between the two constructs may lead to greater innovation in large firms. International Journal of Business and Management, 10(11), 83-93.

24. Creswell, J. W. (2009) 'Educational research Planning, conducting and evaluating quantitative and qualitative research'. ( $2^{\text {nd }}$ ed.) Upper Saddle River, N.J: Pearson Education.

25. Cherchem, N. (2017). The relationship between organisational culture and entrepreneurial orientation in family firms: Does generational involvement matter? Journal of family business strategy, 8(2), 87-98.

26. Easterby-Smith, M., Thorpe, R., Jackson, P. R. (2011.) Management Research ( $3^{\text {rd }}$ ed). London: SAGE Publications.

27. Eddleston, K., \& Kellermanns, F. (2007). Destructive and productive family relationships: A stewardship theory perspective. Journal of Business Venturing, 22(4), 545-565. 
28. Gál, M. (2018). Leadership-Organisational Culture in the light of Public Management reform models: Leadership-Szervezeti kultúra, a közmenedzsment reformok fényében (Doctoral dissertation, Budapesti Corvinus Egyetem).

29. Gao, Y. (2017). Business leaders' personal values, organisational culture and market orientation: Journal of Strategic Marketing, 25(1), 49-64.

30. Genc, E. (2017). Strategy implementation, organisational culture and performance in Turkish local government (Doctoral dissertation, Cardiff University).

31. Ghazikalaye, T. R., \& Roshani, F. (2016). The effect of entrepreneurial orientation on business performance with regard to the role of Customer Relationship Management: International Journal of Humanities and Cultural Studies. 3(2), 1535.

32. Gloss, A., Pollack, J. M., \& Ward, M. K. (2017). A risky shift? An exploration of the measurement equivalence of entrepreneurial attitudes and entrepreneurial orientation across socioeconomic gradients: Journal of Business Venturing Insights, 7, 32-37.

33. Gill, J., \& Johnson, P. (2010). Research methods for managers. Sage.

34. Gefen, D., Straub, D., \& Boudreau, M. C. (2000). Structural equation modeling and regression: Guidelines for research practice. Communications of the association for information systems, 4(1), 7.

35. Gu, W., \& Qian, X. (2019). Does venture capital foster entrepreneurship in an emerging market: Journal of Business Research, 101, 803-810.

36. Kalmuk, G., \& Acar, A. Z. (2015). The mediating role of organisational learning capability on the relationship between innovation and firm's performance: A conceptual framework. Procedia-Social and Behavioural Sciences, 210, 164-169.

37. Kao, C. Y., Tsaur, S. H., \& Wu, T. C. E. (2016). Organisational culture on customer delight in the hospitality industry: International Journal of Hospitality Management, $56,98-108$.

38. Kellermanns, F., Walter, J., Crook, T. R., Kemmerer, B., \& Narayanan, V. (2016). The resource based view in entrepreneurship: A content-analytical comparison of researchers' and entrepreneurs' views. Journal of Small Business Management, 54(1), 26-48.

39. Kohtamäki, M., Heimonen, J., \& Parida, V. (2019). The nonlinear relationship between entrepreneurial orientation and sales growth: The moderating effects of slack resources and absorptive capacity. Journal of Business Research, 100, 100-110.

40. Kowo, S. A., Sabitu, O. L. \& Adegbite (2018). Influence of Competitive Strategies on Corporate Performance of Small and Medium Enterprises, A case from Nigeria: Agricultural and Resource Economics International Scientific Journal, 4 (3), 14-33.

41. Kowo, S. A., Adenuga O. (2019). Correlates of Entrepreneurship Education and Employment Generation Economic and Social Development: Book of Proceedings, 329-342.

42. Kurtulmuş, B. E., \& Warner, B. (2015). Entrepreneurial orientation and perceived financial performance: Does environment always moderate EO performance, 3(5), $19-43$.

43. Lonial, S., \& Carter, R. (2015). The impact of organisational orientations on medium and small firm performance: A resource-based perspective. Journal of Small Business Management, 53(1), 94-113. 
44. Martin, S. \& Javalgi, R. (2016). Entrepreneurial orientation, marketing capabilities and performance: The moderating role of competitive intensity on Latin American international new ventures. Journal of Business Research, 69(6), 2040-2051.

45. Okta, K., Umar, N., Musadiq, A. \& Hamidah, N. (2015). The Influence of Organisational Culture and Entrepreneurial Orientation on the Job Satisfaction, Organisational Commitment and Employee's Performance: European Journal of Business and Management, 7(2), 55-67.

46. Penrose, E. T. (1959). The Theory of the Growth of The Firm. Oxford, GB: Blackwell.

47. Peteraf, M.A. (1993). The cornerstones of competitive advantage: A resourcebased view. Strategic management journal, 14(3), 179-191.

48. Seifari, M., \& Amoozadeh, Z. (2014). The Relationship of Organisational Culture and Entrepreneurship with Effectiveness in Sport Organisations. Annals of Applied Sport Science, 2(3), 51-60.

49. Shahzad, F., Xiu, G., \& Shahbaz, M. (2017). Organisational culture and innovation performance in Pakistan's software industry: Technology in Society, 51, 66-73.

50. Sharma, P., \& Chrisman J. J. (1999). Toward a Reconciliation of the Definitional Issues in the Field of Corporate Entrepreneurship. Entrepreneurship: Theory \& Practice, 23(3), 11-27.

51. Sheng, M. L., \& Chien, I. (2016). Rethinking organisational learning orientation onradical and incremental innovation in high-tech firms: Journal of Business Research, 69(6), 2302-2308.

52. Short, J. C., Zachary, M. A., \& Ketchen Jr, D. J. (2018). Entrepreneurial orientation rhetoric and franchise system size: The moderating role of military veteran recruitment. Journal of Business Venturing Insights, 3 (1), 19-32.

53. Sirén, C., Hakala, H., Wincent, J., \& Grichnik, D. (2017). Breaking the routines: Entrepreneurial orientation, strategic learning, firm size, and age. Long Range Planning, 50(2), 145-167.

54. Şişmanoğlu, E., \& Akçali, B. Y. (2016). The Effect of Innovation on Financia; Performance of Some Information and Technology Companies in Turkey. Ekonometri ve İstatistik e- Dergisi, (24), 82-93.

55. Soedarmono, W., Trinugroho, I., \& Sergi, B. S. (2019). Thresholds in the nexus between financial deepening and firm performance: Evidence from Indonesia. Global Finance Journal, 40, 1-12.

56. Solikahan, E. \& Mohammad, A. (2019). Development of Entrepreneurial Orientation: International Journal of Applied Business \& International Management, 4(1), 31-37.

57. Thomas, E. (2013) Entrepreneurship: A working definition. Harvard Business Review.

58. Ugoji, C., Mordi C. \& Ajonbadi, H. (2014). An investigation into training and development techniques, prospects and challenges in Nigeria Banks: Journal of Research and International Business Management, 4(2), 37-44.

59. Valerio, A., Parton, B., \& Robb, A. (2014). Entrepreneurship Education and Training Programs around the World: Dimensions for Success, World Bank Publications, Washington, DC.

60. Youssef, A. B., Boubaker, S., \& Omri, A. (2018). Entrepreneurship and sustainability: The need for innovative and institutional solutions. Technological Forecasting and Social Change, 129, 232-241. 
56 MEDIATING ROLE OF ENTREPRENEURIAL ORIENTATION, ORGANISATIONAL ..

61. Yildiz, M. L. (2014). The effects of organisational culture on corporate entrepreneurship: International journal of business and social science, 5(5), 35-44.

62. Zampetakis, L. A., Lerakis, M., Kafetsios, K., \& Moustakis, V. (2015). Investigating the emotional impact of entrepreneurship programs, Journal of Business Venturing Insights, 4, 38-41. 